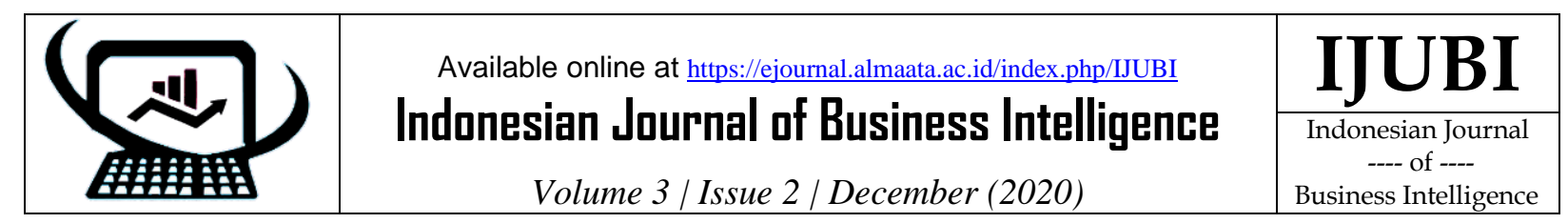

\title{
KLASIFIKASI DIAGNOSA PERADANGAN KANDUNG KEMIH MENGGUNAKAN METODE ALGORITMA NAÏVE BAYES
}

Muhammad Muharrom ${ }^{1}$

1Prodi Teknologi Informasi, Fakultas Teknik dan Informatika, Universitas Bina Sarana Informatika, muhammad.muu@bsi.ac.id

Jl. Krmat Raya No.98, Senen. Jakarta Pusat 10450 Telp. (021)23231170 Fax (021) 21236158

Keywords:

Disease, Nä̈ve Bayes, diagnosis

\section{Kata Kunci:}

Penyakit, Naïve bayes, diagnosa
Inflammation of the bladder is one of the diseases caused by pain when urinating, the pain comes from the urinary tract which is between the parts that need a diagnosis such as patient temperature $\{35 \mathrm{C}-42 \mathrm{C}\}$, occurrence of nausea $\{y e s, n o\}$ back pain \{yes, no\}, Pushing urine (need to urinate constantly) \{yes, no\}, urinary pain \{yes, no\}, Burning of the urethra, itching, swelling of the urethral outlet \{yes, no\}. To understand the problem better, it is necessary to research in order to prevent the worsening of the disease by classifying patient data to accurate disease outcomes suffered by patients and to be able to predict from existing data. The dataset is obtained from public datasets which can be used for research and the method used is Naïve Bayes, one of the classification algorithms that is quite reliable and is assisted by rapid mining tools to analyze its accuracy. By using the naive Bayes method in the calculation, the compatibility between manual calculations using rapidminer tools and the resulting accuracy is $90.8 \%$ and the ROC calculation results in an AUC value of 0.956 which means excellent classification.

Abstrak
Peradangan pada kandung kemih adalah salah satu penyakit yang
ditimbulkan dari rasa nyeri saat buang air kecil, rasa nyeri itu berasal dari
saluran kemih yang diantara bagian yang perlu diagnosis seperti Suhu
pasien \{35C-42C\}, Terjadinya mual \{ya, tidak\} Nyeri Pinggang \{ya, tidak\},
Mendorong urin (kebutuhan untuk buang air kecil terus-menerus) \{ya,
tidak\}, Sakit berkemih \{ya, tidak\}, Pembakaran uretra, gatal, pembengkakan
saluran keluar uretra \{ya, tidak\}. Untuk memahami masalah dengan lebih
baik, Maka perlunya penelitian agar dapat mencegah semakin parahnya
penyakit yang diderita dengan cara mengklasifikasikan data pasien untuk
mengakurasikan hasil penyakit yang di derita oleh pasien dan dapat
memprediksi dari data yang ada. Dataset didapatkan dari dataset publik
yang mana dapat digunakan untuk penelitian dan metode yang digunakan
adalah nä̈ve bayes salah satu algoritma klasifikasi yang cukup handal dan
dibantu dengan tools rapid miner untuk menganalias keakuratannya.
Dengan menggunakan metode naïve bayes dalam perhitungan dihasilkan
kesesuaian antara perhitungan manual dengan menggunakan tools
rapidminer dan dihasilkannya keakuratan adalah 90,8\% dan perhitungan
ROC menghasilkan nilai AUC adalah 0.956 yang berarti excellent
classification.

maka mudah terserang penyakit. Salah satunya sering terjadi yaitu penyakit akibat infeksi. Penyakit ini biasanya disebabkan oleh jamur, bakteri, jamur maupun virus. Risiko seseorang untuk terkena penyakit infeksi bisa meningkat

\section{Pendahuluan}

Pada dasarnya kesehatan adalah salah satu faktor utama yang harus dijaga pada manusia. Apabila tubuh dalam kedaan kurang sehat

31 "Muhammad Muharrom" 
apabila ia memiliki kondisi medis tertentu seperti memiliki data tahan tubuh yang sedang melebah. Infeksi saluran kemih adalah salah satu penyakit yang merupakan reaksi inflamasi sel-sel uroepitelium yang melapisi saluran kemih yang dapat mengenai laki-laki maupun perempuan semua umur yang dapat beresiko terhadap kesehatan tubuh manusia.

Menurut Sjahrurrachaman "banyaknya infeksi kandung kemih disebabkan oleh bakteri yang mengendap dan hanya sebagian kecil yang disebabkan oleh jamur atau virus. Sehingga pengobatan yang utama pada infeksi kandung kemih adalah antibakteri"[1]. Pemeriksaan terhadap urin salah satu pemegang peranan penting dalam memonitoring penyakit infeksi saluran kemih. Jumlah hasil leukosit yang banyak di dalam urin menandakan adanya suatu infeksi atau radang pada saluran kemih yang didapatkan. Leukosit di dalam urin dapat dilihat dengan beberapa cara, salah satunya adalah sedimen urin leukosit. Sedimen urin leukosit dapat memberi informasi penting bagi klinis dalam membantu menegakkan diagnosis dan memantau perjalanan penyakit di saluran kemih.

Pada penelitian ini dilakukan untuk mengetahui perhitungan data diagnosa dugaan peradangan kandung kemih serta membandingkan dengan tools aplikasi rapid miner menggunakan algoritma Naïve Bayes. Menurut Prasetyo "Naive Bayes merupakan salah satu teknik prediksi klasifikasi yang berbasis probabilistik sederhana yang berdasarkan pada penerapan teorema Bayes (aturan Bayes) dengan asumsi independensi (ketidaktergantungan) yang kuat (naif) berdasarkan atribut yang sudah ditentukan. Dengan kata lain, dalam Naive Bayes model yang digunakan adalah "model fitur independen" [2].

Penggunaan data mining klasifikasi dengan algoritma Naive Bayes sebagai pilihan untuk prediksi diagnosa peradangan kandung kemih yang dapat menjadi alternatif pilihan yang tepat. Ruang lingkup pada penelitian ini dengan menggunakan data pasien yang didapatkan dari University of California Irvine Machine Learning Repository, kemudian mengevaluasi hasil algoritma tersebut untuk mengetahui metode klasifikasi dan tingkat keakuratan dengan tools rapid miner.

\section{Landasan Teori}

\section{A. Data Mining}

Data mining adalah proses yang menggunakan statistik, matematika, kecerdasan buatan, dan machine learning untuk mengekstraksi dan mengidentifikasi informasi yang bermanfaat. Data Mining didefinisikan sebagai proses penemuan pola dalam data. Berdasarkan tugasnya, data mining dikelompokkan menjadi deskripsi, estimasi, prediksi, klasifikasi, clustering dan asosiasi. Proses dalam tahap data mining terdiri dari tiga langkah Utama, yaitu data Preparation Pada langkah ini, data dipilih, dibersihkan, dan dilakukan preprocessed mengikuti pedoman dan knowledge dari ahli domain yang menangkap dan mengintegrasikan data internal dan eksternal ke dalam tinjauan organisasi secara menyeluruh. Penggunaan algoritma data mining dilakukan untuk menggali data yang terintegrasi untuk memudahkan identifikasi informasi bernilai [3]. Namun semakin besar data yang diolah maka semakin besar pula waktu prosesnya [4].

\section{B. Algoritma}

Kata algoritma (algorithm) kata tersebut berasal dari kata algorism yang diambil dari nama seorang penulis buku Arab yang terkenal, yaitu Abu Ja'far Muhammad ibnu Musa AlKhuwarizmi (al-Khuwarizmi dibaca orang Barat menjadi algorism) [5].

Adapun pengertian algoritma adalah kumpulan suatu instruksi atau suatu perintah yang dibuat secara jelas, detail dan sistematis berdasarkan urutan yang logis yang dapat diterima oleh akal untuk penyelesaian suatu masalah sesuai dengan tingkat yang sudah di tentukan. 5 komponen utama dalam algoritma yaitu finiteness, definitenesss, input, output dan effectiveness. Sehingga dalam merancang sebuah algoritma ada tiga komponen yang harus ada yaitu:

1. Komponen masukan (input)

Komponen ini biasanya terdiri dari pemilihan variabel, jenis variabel, tipe 
variabel, konstanta dan paramenter (dalam fungsi).

2. Komponen keluaran (output)

Komponen ini merupakan tujuan dari perancangan algoritma dan program. Permasalahan yang diselesaikan dalam algoritma dan program harus ditampilkan dalam komponen keluaran. Karakteristik keluaran yang baik adalah keluaran yang benar menjawab permasalahan dan tampilan (interface) yang ramah.

3. Komponen proses (processing)

Komponen ini merupakan bagian utama dan terpenting dalam merancang sebuah algoritma. Dalam bagian ini terdapat logika masalah, logika algoritma (sintaksis dan semantik), rumusan, metode (rekursi, perbandingan, penggabungan, pengurangan dan lain-lain).

Adapun jika dilihat dari segi kondisinya, kompoenen algoritma terdiri dari dua kondisi yaitu:

1. Pre condition adalah kondisi suatu program ketika proses algoritma siap untuk dijalankan (sebelum dilaksanakan algoritma). Dengan kata lain pre condition merupakan kondisi awal dimana proses algoritma akan dijalankan. Pre condition dinyatakan dengan mendefinisikan input dari sebuah algoritma berdasarkan pengetahuan dan data yang ada.

2. Post condition

Post condition merupakan kondisi setelah suatu algoritma selesai dijalankan. Post condition dinyatakan dengan mendefinisikan hasil (output) dari suatu algoritma untuk mencapai suatu hasil yang telah ditentukan sebelumnya.

\section{Nä̈ve Bayes}

Menurut Prasetyo "Bayes merupakan teknik prediksi berbasis probabilistik sederhana yang berdasar pada penerapan teorema Bayes. Klasifikasi Naive Bayes praktis diterapkan karena merupakan salah satu probabilitas sederhana yang penerapannya didasarkan pada teorema bayes dengan asumsi independensi $[6] "$.

Tahapan dari proses algoritma Naive Bayes adalah:

1). Menghitung jumlah kelas / label.

33 "Muhammad Muharrom"
2). Menghitung Jumlah Kasus Per Kelas

3). Kalikan Semua Variable Kelas

4). Bandingkan Hasil Per Kelas

\section{Confusion Matrix}

Merupakan suatu cara untuk memberikan rincian secara klasifikasi, kelas yang diprediksi akan ditampilkan di bagian atas matrix dan kelas yang diobservasi ditampilkan di bagian kiri [7].

Evaluasi model confussion matrix menggunakan tabel seperti matrix dibawah ini:

Tabel 1. Model Confusion Matrix

\begin{tabular}{l|l|l|l}
\hline CLASSIFICATION & \multicolumn{3}{|c}{ PREDICTED CLASS } \\
\hline Observed Class & & $\begin{array}{l}\text { Class= } \\
\text { Yes }\end{array}$ & Class= No \\
& & True & False \\
& Class= & Positive- & Negative- \\
& Yes & (TP) & (FN) \\
\cline { 2 - 4 } & & False & True \\
\cline { 2 - 4 } & Class- & Positive- & Negative- \\
& No & (FP) & (TN)
\end{tabular}

Akurasi dapat dihitung dengan menggunakan rumus berikut:

$$
\text { Accuracy }=(\mathrm{TP}+\mathrm{TN}) /(\mathrm{TP}+\mathrm{TN}+\mathrm{FP}+\mathrm{FN})
$$

$\mathrm{TP}$ : Jumlah kasus positif yang diklasifikasikan sebagai positif

FP : Jumlah kasus negatif yang diklasifikasikan sebagai positif

TN : Jumlah kasus negatif yang diklasifikasikan sebagai negatif

FN : Jumlah kasus positif yang diklasifikasikan sebagai negatif.

\section{E. Kurva ROC}

Kurva ini banyak digunakan untuk menilai hasil prediksi, kurva ROC adalah teknik untuk memvisualisasikan, mengatur, dan memilih pengklasifikasian berdasarkan kinerja mereka. Kurva ROC adalah peralatan dua dimensi yang digunakan untuk menilai kinerja klasifikasi yang menggunakan dua class keputusan, masing- masing objek dipetakan ke salah satu elemen dari himpunan pasangan, positif atau negatif. Pada kurva ROC, TP rate diplot pada sumbu $\mathrm{Y}$ dan FP rate diplot pada sumbu $\mathrm{X}$. 
Untuk klasifikasi data mining, nilai AUC dapat dibagi menjadi beberapa kelompok [7].

a) $0.90-1.00=$ Excellent Classification

b) $0.80-0.90=$ Good Classification

c) $0.70-0.80=$ Fair Classification

d) $0.60-0.70=$ Poor Classification

e) $0.50-0.60=$ Failur

\section{F. Rapid Miner}

Rapid Miner adalah platform perangkat lunak data ilmu pengetahuan yang dikembangkan oleh perusahaan dengan nama yang sama, yang menyediakan lingkungan terpadu untuk pembelajaran mesin (machine learning). Pembelajaran mendalam (deep learning), penambangan teks (teks mining) dan analisis prediktif (predictive analytic). Aplikasi ini digunakan untuk aplikasi bisnis dan komersial serta untuk penelitian, pendidikan, pelatihan, pembuatan prototype dengan cepat, dan pengembangan aplikasi serta mendukung semua langkah proses pembelajaran mesin termasuk persiapan data, visualisasi hasil validasi dan pengoptimalan.[8]

\section{Metode Pengumpulan Data}

Berikut adalah Teknik pengumpulan data yang digunakan dalam proses penelitian ini:

Adapun perancangan pada penelitian telah disusun sehingga alur dari proses penelitian ini sesuai dengan yang telah ditentukan. penelitian ini menggunakan kuantitatif yang digunakan untuk meneliti pada populasi atau sample tertentu, pengumpulan data menggunakan instrumen penelitian, analisis data bersifat kuantitatif/statistik dengan tujuan untuk menguji hipotesis yang telah ditentukan.

Penelitian ini dilakukan dengan menjalankan beberapa langkah proses penelitian, yaitu:

\section{1) Pengumpulan Data}

Data pasien diperoleh dari University of California Irvine Machine Learning Data Repository, Dataset ini banyak digunakan oleh peneliti untuk menguji algoritma klasifikasi. Dataset ini berisikan 120 record dengan 6 atribut. Dataset ini merupakan dataset yang dapat digunakan untuk klasifikasi penyakit Peradangan Kandung Kemih [9].

\section{2) Pengolahan Awal Data}

Pada tahap ini data yang masih berupa nilai numerik dan juga continue ditransformasikan kedalam bentuk kategorikal dan dibuat skala atau interval sehingga menghasilkan range yang lebih kecil sebagai bahan pembelajaran algoritma Naive Bayes akan lebih mudah di klasifikasikan dengan menggunakan Rapid Miner sehingga memudahkan dalam memproses klasifikasi pada dataset yang telah tersedia sebelumnya.

\section{3) Penerapan Algoritma Naive Bayes dan Tools Rapid Miner}

Pada tahap ini memilih dan menerapkan teknik yang tepat untuk mendapatkan hasil yang optimal, pada penelitian ini algoritma yang digunakan adalah algoritma Naive Bayes dilakukan dengan data uji. tahap ini dilakukan dengan bantuan tools Rapid Miner .70.

\section{4) Analisa Hasil perhitungan}

Pada penelitian ini dilakukan analisa terhadap hasil yang diperoleh lewat perhitungan manual dan menggunakan tools rapid miner untuk mengetahui kesesuaikan antara perhitungan manual dengan menggunakan tools rapid miner. Pengukuran dilakukan menggunakan metode Confusion Matrix dan Kurva ROC beserta Area Under the Curve-nya.

\section{Hasil dan Pembahasan}

Pada tahap ini dilakukan eksperimen dan pengujian metode yang digunakan yaitu menghitung dengan menggunakan algoritma yang diusulkan yaitu Algoritma Naïve Bayes. Adapun atribut yang digunakan adalah: Suhu pasien \{35C-42C\}, Terjadinya mual \{ya, tidak\} Nyeri Pinggang \{ya, tidak\}, Mendorong urin (kebutuhan untuk buang air kecil terusmenerus) \{ya, tidak\}, Sakit berkemih \{ya, tidak\} Pembakaran uretra, gatal, pembengkakan saluran keluar uretra \{ya, tidak\}, Keputusan: Peradangan kandung kemih \{ya, tidak\}.

Adapun dibuat satu data yang digunakan untuk pengujian yang nanti akan disesuaikan hasilnya antara perhitungan manual dan menggunakan tools Rapidminer sebagai berikut: 
Data testing: '40 'Suhu pasien, 'No' Terjadinya mual, 'No' sakit pinggang, 'Yes'Mendorong urin (kebutuhan buang air kecil terus menerus), 'Yes' Nyeri berkemih, 'Yes'Terbakarnya uretra, gatal, bengkaknya saluran keluar uretra, Keputusan Peradangan kandung kemih disesuaikan dari prediksi dari data yang ada sebanya 120 data.

Langkah Pertama: Menghitung jumlah kelas/label: Keputusan: Peradangan kandung kemih: "No"= 61/120 "Yes" = 59/120. Langkah Kedua: Menghitung Jumlah Kasus Per Kelas.

Suhu Pasien (35C-42C): "No" =5/61 "Yes" =3/59 Terjadinya mual: "No" $=51 / 61$ "Yes" $=40 / 59$ Nyeri Pinggang: "No"=10/61 "Yes" $=40 / 59$. Mendorong urin (kebutuhan terus-menerus untuk buang air kecil): "No" $=21 / 61$ "Yes" $=59 / 59$. Rasa sakit berkemih: "No"=10/61

"Yes" =49/59. Pembakaran uretra, gatal, bengkaknya saluran keluar uretra: "No" $=21 / 61$ "Yes"=29/59. Langkah Ketiga: Kalikan Semua Variable Kelas Kelas No:

$=5 / 61 \times 51 / 61 \times 10 / 61 \times 21 / 61 \times 10 / 61 \times 21 / 61$

$=0,0819672131147541 \times 0,836065573770492 \times 0,163$

$934426229508 \times 0,344262295081967 \times 0,1639344262$

$29508 \times 0,344262295081967$

$=0,0000000000$

Kelas Yes:

$=3 / 59 * 40 / 59 * 40 / 59 * 59 / 59 * 49 / 59 * 29 / 59$

$=0,0508474576271186 \times 0,677966101694915 \times 0,677$

$966101694915 \times 1 \times 0,830508474576271 \times 0,49152542$

$3728814=0,0095405905$

Langkah terakhir adalah membandingkan mana nilai hasil perhitungan yang lebih besar, karena kelas "YES" memiliki nilai lebih besar maka hasil prediksi dari algoritma naïve bayes terhadap data tersebut adalah "Keputusan: Peradangan kandung kemih = "YES".

Adapun menggunakan tools rapidminer sehingga dapat diketahui secara otomatis prediksi yang dilakukan sebagai berikut:

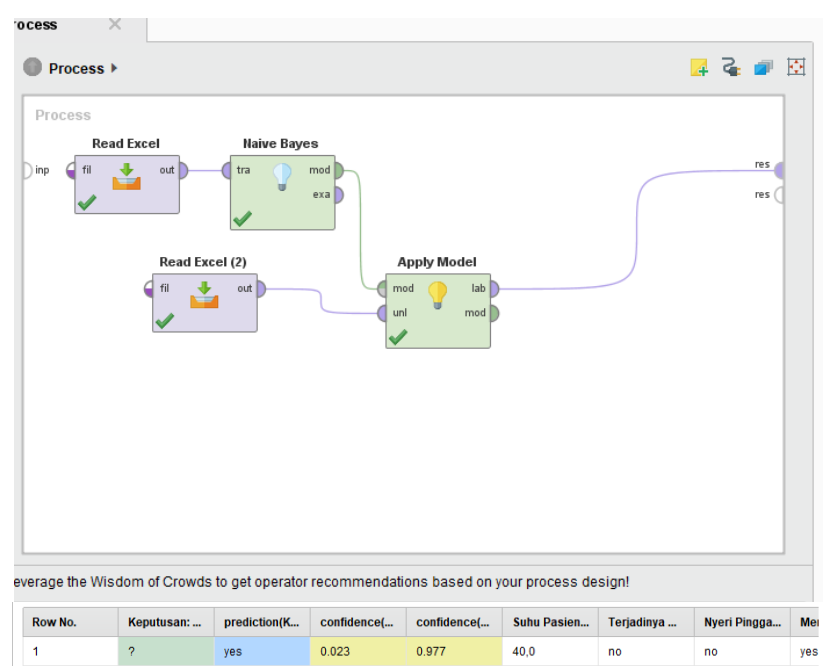

Gambar 1. Model klasifikasi naïve bayes Hasil yang didapat prediksi adalah yes, sesuai dengan perhitungan manual.

Adapun untuk model yang digunakan pada aplikasi rapid miner adalah

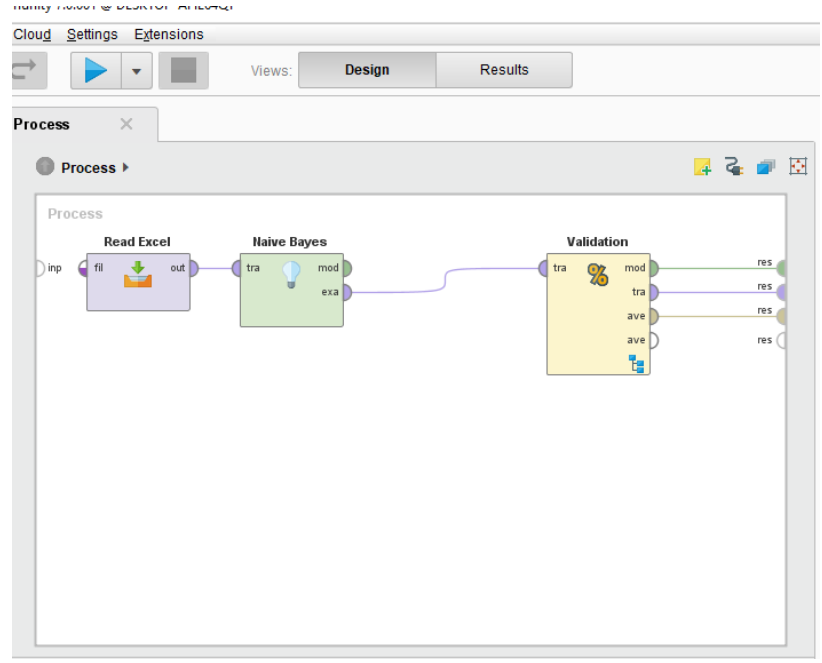

Gambar 2. Model Pengujian Validasi Naïve Bayes

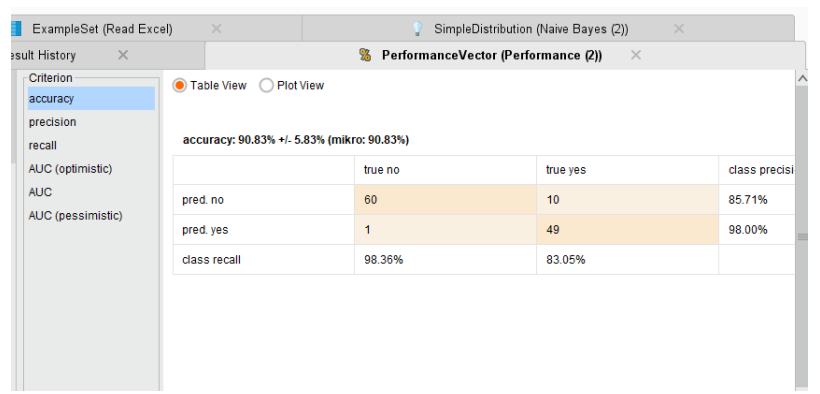

Gambar 3. Percobaan model confusion matrix

Berdasarkan gambar 3 menunjukan bahwa, diketahui dari 120 data pasien, hasil data testing pada tabel confusion matrix diatas ada 60 pasien diprediksi negatif maka hasilnya 
sesuai dengan prediksi yaitu negatif, 10 pasien diprediksi negatif tetapi hasilnya adalah positif, sedangkan ada 1 pasien yang diprediksi positif tetapi hasilnya adalah negatif dan 49 diprediksi positif maka hasilnya sesuai dengan prediksi yaitu positif tingkat akurasi dengan menggunakan algoritma Naive Bayes adalah $90.83 \%$, dan dapat dihitung untuk mencari nilai accuracy, yaitu:

Keterangan:

$\mathrm{TP}=49$

$\mathrm{FP}=1$

$\mathrm{TN}=60$

$\mathrm{FN}=10$

$$
\begin{aligned}
\text { Akurasi } & =(\mathrm{TP}+\mathrm{TN}) /(\mathrm{TP}+\mathrm{TN}+\mathrm{FP}+\mathrm{FN}) \\
= & (49+60) /(49+60+1+10) \\
= & 0.9083(90.83 \%
\end{aligned}
$$

Sedangkan hasil perhitungan divisualisasikan dengan kurva ROC Naive Bayes. Kurva ROC pada gambar 4mengekspresikan confusion matrix. Garis horizontal adalah false positives dan garis vertikal true positives.

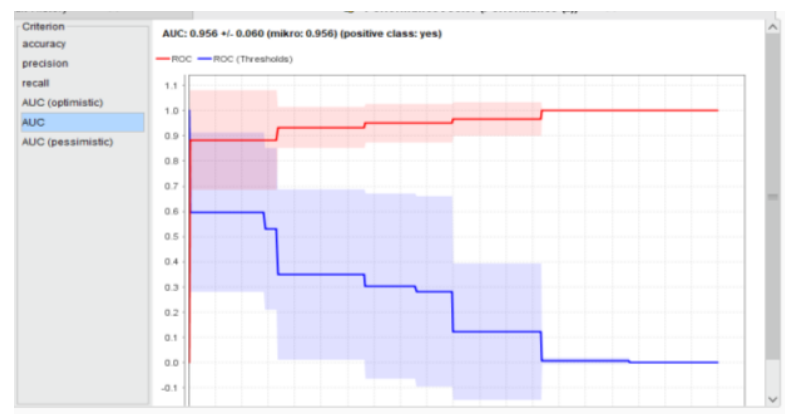

Gambar 4. Kurva ROC

Dari Gambar 4 terdapat grafik ROC dengan nilai AUC (Area Under Curve) sebesar 0.956 dimana diagnosa hasilnya Excellent Classification.

\section{Kesimpulan dan Saran}

Berdasarkan perumusan masalah dan serangkaian penelitian yang telah penulis lakukan. Maka dapat disimpulkan beberapa hal sebagai berikut :

1. Dilakukan proses perhitungan manual menggunakan algoritma naïve bayes dengan data testing menghasilkan prediksi yang sesuai dengan menggunakan tools rapid miner.

2. Jika dilakukan proses tingkat akurasi pada rapidminer dari dataset yang ada menghasilkan nilai keakuratan 90,8\% yang

36 "Muhammad Muharrom" berarti cukup tinggi dilakukan dengan metode naïve bayes.

3. Hasil perhitungan ROC menggunakan algoritma naïve bayes menghasilkan nilai AUC adalah 0.956 yang berarti excellent classification.

Berikut ini beberapa saran yang dapat dipergunakan untuk pengembangan penelitian ini adalah.

1. Perlu adanya percobaan pada algoritma yang lain seperti $k-N N$ atau Decision tree guna untuk dapat mengetahui hasil kekuartan dari metode klasifikasi yang lain serta tingkat keakuratannya.

2. Menggunakan data yang real time, atau yang terbaru, sehingga sangat akurat dalam menentukan hasil dan sesuai perkembangan saat ini.

\section{Referensi}

[1] Endriani, R., Andrini, F., \& Alfina, D. (2010). Pola resistensi bakteri penyebab infeksi saluran kemih (ISK) terhadap antibakteri di pekanbaru. Jurnal Natur Indonesia, 12(02), 130-135.

[2] Aji, P. B. (2016). Sistem Diagnosa Dini Penyakit Paru Dengan Metode Naïve Bayes. STMIK Sinar Nusantara Surakarta. eprints.sinus.ac.id/443/

[3] M. M. Baharuddin, T. Hasanuddin, and H. Azis, "Analisis Performa Metode K-Nearest Neighbor untuk Identifikasi Jenis Kaca," Ilk. J. Ilm., vol. 11, no. 28, pp. 269-274, 2019.

[4] A. Ilham, "Komparasi Algoritma Klasifikasi Dengan Pendekatan Level Data Untuk Menangani Data Kelas Tidak Seimbang," J. Ilm. Ilmu Komput., vol. 3, no. 1, pp. 9-14, 2017.

[5] Munir, Rinaldi. (2012). Matematika Diskrit. Bandung: Informatika.

[6] Dewi, I. C., Soebroto, A. A., \& Furqon, M. T. (2015). Sistem Pakar Diagnosa Penyakit Sapi Potong Dengan Metode Naive Bayes. Journal of Environmental Engineering and Sustainable Technology, 2(2), 72-78.

[7] Gorunescu, Florin. (2011). Data Mining Concepts, Models and Techniques. 
[8] Ramdan, Nur Ariesanto., Abdul K, Agyztia Preman. (2020). Modul Belajar Data Mining \& RapidMiner.Klaten: Lakeisha.
[9] Dataset diakses 15 Oktober 2020. https://archive.ics.uci.edu/ml/datasets/A cute+Inflammations 